BIODIK: Jurnal IImiah Pendidikan Biologi
ISSN 2580-0922 (online), ISSN 2460-2612 (print)
Volume 7, Nomor 02, Tahun 2021, Hal. 205-215
Available online at:
hIOD:/Konline-journal.unja.ac.id/biodik

Research Article

\title{
Analisis dan Rekonstruksi Lembar Kegiatan Peserta Didik pada Materi Sistem Indera Penglihatan Manusia
}

\section{(Analysis and Reconstruction of Student Worksheet of Human Visual Sensory System)}

\author{
Yusnita Renata Tamba*, Sri Anggraeni, Bambang Supriatno \\ Universitas Pendidikan Indonesia \\ Jalan Dr. Setiabudi No. 299, Bandung, 40154, Indonesia \\ *Corresponding Author: yusnitart@upi.edu
}

\begin{tabular}{|c|c|}
\hline Informasi Artikel & ABSTRACT \\
\hline $\begin{array}{l}\text { Submit: } 25-05-2021 \\
\text { Diterima: } 01-06-2021 \\
\text { Dipublikasikan: } 21-06-2021\end{array}$ & $\begin{array}{l}\text { Practical activities are one of the ways used to provide opportunities for } \\
\text { students to learn independently and construct their own knowledge. In doing } \\
\text { practicum, students use LKPD which contains objectives, tools, materials and } \\
\text { work steps that will be carried out by students. The purpose of this study was to } \\
\text { analyze and describe the conceptual, competency, practical and knowledge } \\
\text { construction components used by students in studying the human visual sense } \\
\text { system. The sample used in this study consisted of nine textbooks published } \\
\text { from } 2009 \text { to } 2019 \text { which were selected using a purposive sampling technique. } \\
\text { The analysis was carried out using instruments made based on the Vee } \\
\text { diagram. The results of the analysis found that the LKPD used had not been } \\
\text { able to meet the minimum standards of basic competencies that had been set } \\
\text { in the curriculum. LKPD needs to be reconstructed and developed again to } \\
\text { achieve at least a minimum standard of competence. }\end{array}$ \\
\hline & Key words: Student Worksheet, Visual Sensory System \\
\hline Penerbit & ABSTRAK \\
\hline $\begin{array}{l}\text { Program Studi Pendidikan Biologi } \\
\text { FKIP Universitas Jambi, } \\
\text { Jambi- Indonesia }\end{array}$ & $\begin{array}{l}\text { Kegiatan praktikum menjadi salah satu cara yang digunakan dalam memberi } \\
\text { kesempatan bagi siswa untuk belajar mandiri dan mengonstruksi } \\
\text { pengetahuannya sendiri. Dalam melakukan praktikum, siswa menggunakan } \\
\text { LKPD yang memuat tujuan, alat, bahan serta langkah kerja yang akan } \\
\text { dilakukan oleh siswa. Tujuan dari penelitian ini adalah untuk menganalisis dan } \\
\text { mendeskripsikan komponen LKPD dari aspek relevansi dengan kurikulum, } \\
\text { kompetensi, praktikal dan konstruksi pengetahuan yang dipakai siswa dalam } \\
\text { mempelajari materi sistem indera penglihatan manusia. Adapun sampel yang } \\
\text { dipakai dalam penelitian ini terdiri atas sembilan buku pelajaran yang terbit dari } \\
\text { tahun } 2009 \text { hingga } 2019 \text { yang dipilih dengan teknik purposive sampling. } \\
\text { Analisis dilakukan menggunakan instrumen yang dibuat berdasarkan diagram } \\
\text { Vee. Hasil analisis ditemukan bahwa LKPD yang digunakan belum dapat } \\
\text { memenuhi standar minimum kompetensi dasar yang sudah ditetapkan dalam } \\
\text { kurikulum. LKPD indera penglihatan perlu direkonstruksi dan dikembangkan } \\
\text { lagi untuk mencapai setidaknya standar minimal kompetensi. }\end{array}$ \\
\hline & Kata kunci: LKPD, Sistem Indera Penglihatan \\
\hline
\end{tabular}

This BIODIK : Jurnal IImiah Pendidikan Biologi is licensed under a CC BY-NC-SA (Creative Commons Attribution-ShareAlike 4.0 International License) 


\section{PENDAHULUAN}

Pendidikan bertujuan untuk meningkatkan mutu dan menggali potensi serta kemampuan manusia sejak dini (Hidayah, 2012). Pentingnya pendidikan menyebabkan proses yang terjadi didalamnya harus dapat terjadi dengan baik. Perkembangan pendidikan saat ini menekankan pada pembelajaran efektif dan mandiri yang menyediakan kesempatan bagi siswa untuk memperoleh pengetahuan dari pemahamannya sendiri (Lahra, 2017). Pembelajaran dengan student centered learning (SCL) diyakini sebagai cara yang lebih efektif dibandingkan dengan teacher centered learning yang sudah lama menjadi cara yang dilakukan disekolah sejak dulu. Attard (2010) menyebutkkan bahwa SCL mendukung situasi pembelajaran yang terpusat pada siswa, sehingga dalam proses pembelajarannya siswa terlibat aktif untuk membangun konsep yang dituntut oleh kurikulum, sementara guru bertindak sebagai fasilitator.

Salah satu cara yang dapat dilakukan dalam menyediakan pembelajaran efektif yang berpusat pada siswa adalah kegiatan praktikum. Kegiatan praktikum dapat mengembangkan bukan saja kemampuan kognitif siswa, namun juga kemampuan psikomotor dan afektif siswa (Hindriana, 2016). Hal ini dapat terjadi karena melalui kegiatan praktikum, siswa dapat mengembangkan sendiri pemahamannya dengan menerima pengalaman secara langsung (Wahidah, 2018). Siswa diberikan kesempatan untuk mengembangkan kegiatan, mengobservasi bahkan memanipulasi suatu objek sehingga siswa dapat mengonstruksi pengetahuannya sendiri berdasarkan informasi faktual yang diterimanya (Supriatno, 2018). Adapun konstruksi pengetahuan dapat terjadi karena siswa mengobservasi peristiwa atau objek dan mengaitkannya dengan pengetahuan yang dimiliki, sehingga terbentuk suatu konsep baru (Novak \& Gowin, 1984). Studi analisis manfaat kegiatan praktek menunjukkan bahwa kegiatan praktek berperan besar dalam meningkatkan kemampuan laboratorium dan pengetahuan saintifik serta pemahaman terhadap konsep dan teori (Shana, 2020). Kegiatan praktek diyakini dapat meningkatkan sikap serta motivasi secara positif terhadap efektifitas pembelajaran siswa dan juga lebih berguna dan menyenangkan dibanding aktivitas belajar mengajar lainnya (Okam \& Zakari ,2017; Abrahams \& Millar, 2008).

Untuk membantu siswa dalam mencapai hasil maksimal dalam kegiatan praktek, diperlukan sebuah rancangan kegiatan praktikum yang dapat mengarahkan siswa dalam bekerja secara ilmiah (Furqan, Yusrizal \& Saminan, 2016 Buku pelajaran menjadi salah satu unsur penting yang mempengaruhi kegiatan belajar siswa. Materi dan konsep, kegiatan serta soal-soal yang termuat dalam buku akan mempengaruhi pola pikir dan pemahaman siswa (Ritonga, 2016). ). Saat ini, hampir seluruh buku pelajaran yang beredar di Indonesia memuat kegiatan praktek untuk siswa. Rancangan kegiatan praktek dipakai siswa memiliki banyak kekurangan, salah satunya langkah kerja yang tidak terstruktur dengan baik sehingga objek/fenomena yang perlu diamati tidak dapat terlihat (Ramadhayanti, 2020). Selain itu, kegiatan yang tersedia juga cenderung tidak dapat menyediakan pengalaman bermakna yang dibutuhkan siswa dalam belajar karena bertujuan untuk membuktikan konsep yang sudah dipelajari siswa dengan mengikuti lembar kerja yang telah disediakan (Lestari, R., Supriatno, B \& Anggraeni, 2020).

Salah satu materi yang ada di kelas XI yang menjadi fokus pengamatan dalam penelitian ini adalah materi sistem regulasi. Materi ini merupakan salah satu materi yang memiliki cakupan luas dan sulit bagi siswa (Hidayati, N. 2015). Materi ini terdiri atas beberapa sistem berkaitan yaitu sistem saraf, 
sistem endokrin dan sistem indera dan dirangkum dalam satu kompetensi dasar yang harus dikuasai siswa. Kompetensi dasar terkait yaitu menganalisis hubungan antara struktur jaringan penyusun organ pada sistem koordinasi (saraf, hormone dan alat indera) dalam kaitannya dengan mekanisme koordinasi dan regulasi serta gangguan fungsi yang dapat terjadi pada sistem koordinasi manusia (Kemendikbud, 2018). Hal ini tentu lebih sulit untuk dipelajari karena mengandung banyak fenomena, tidak seperti materi lainnya misalnya materi sistem pencernaan yang hanya menjelaskan organ dan mekanisme pencernaan didalamnya. Pada materi sistem koordinasi ini, siswa dituntut untuk mampu mengaitkan ketiga materi tersebut dalam fungsinya sebagai sistem koordinasi dalam tubuh. Kenyataannya, kegiatan praktikum yang ada di LKPD hanya menjabarkan bagaimana salah satu bagian bekerja dan tidak mengaitkannya pada sistem lain. Materi yang menjadi sorotan pada penelitian ini adalah sistem indera penglihatan. Dari berbagai sumber buku yang dikumpulkan, hanya ada satu kegiatan yang menjadi fokus utama dalam praktikum, yaitu mengetahui adanya bintik buta pada mata. Apabila dilihat dari isi tuntutan KD-nya, kegiatan ini tentu tidak mampu membantu siswa dalam mencapai kompetensi seperti yang diharapkan dalam kurikulum. Berdasarkan hal tersebut, maka dilakukanlah penelitian yang bertujuan untuk menganalisis LKPD siswa pada materi sistem indera penglihatan dan merekonstruksi LKPD untuk mencapai standar kompetensi yang sesuai dengan kurikulum yang berlaku.

\section{METODE PENELITIAN}

Metode penelitian yang dipakai dalam penelitian ini adalah metode deskriptif-kualitatif yang bertujuan untuk mengumpulkan data dan menganalisa faktor-faktor yang berkaitan dengan objek penelitian (Prabowo, 2013). Adapun objek pada penelitian ini adalah LKPD pada materi sistem Indera yang difokuskan pada Sistem Indera Penglihatan - Bintik Buta pada Mata. Sampel diambil dengan teknik purpossive sampling, yaitu teknik yang mengambil sampel berdasarkan pertimbangan tertentu terkait dengan objek penelitian (Arikunto, 2003). Adapun pertimbangan yang dipakai adalah buku-buku yang memuat LKPD mengenai bintik buta pada mata. Sampel yang dipakai berjumlah 9 buku yang terbit dari tahun 2009 hingga 2019 dimana 2 buku diantaranya disusun berdasarkan KTSP 2006, 1 buku dari Kurikulum 2013 dan 6 buku lainnya dari Kurikulum 2013 Revisi 2016.

Kegiatan penelitian dilakukan dalam 3 tahapan, yakni tahap (1) menganalisis LKPD yang sudah ditetapkan sebelumnya. Pada tahap ini, analisis dilakukan dengan menggunakan instrumen yang diadaptasi dan dikembangkan dari beberapa ahli dan di validasi oleh dosen ahli. Adapun aspek yang menjadi fokus dalam instrumen dapat dilihat pada tabel 1. Tahap (2) menguji coba salah satu LKPD yang bertujuan untuk menemukan kekurangan dan kelebihan dari LKPD tersebut sebagai bahan dalam pertimbangan tahap selanjutnya. Tahap (3) membuat ataupun merekonstruksi LKPD berdasarkan hasil analisis dan hasil uji coba yang sudah dilakukan sebelumnya. 
Tabel 1. Aspek yang dianalisis dalam Instrumen Penelitian

\begin{tabular}{cllc}
\hline No & \multicolumn{1}{c}{ Aspek } & \multicolumn{1}{c}{ Indikator } & Skor Maksimal \\
\hline 1 & Relevansi dengan Kurikulum & Kompetensi dengan KD & 3 \\
& & Konten dengan KD & 3 \\
\hline 2 & Kompetensi & Kemampuan Observasi & 4 \\
& & Representasi Data (Miler \& Huberman, & 4 \\
& & 1984) & \\
& & Interpretasi Data (Bertin, 1983; & 4 \\
& & Creswell, 2016) \\
& & Level Kemampuan Berpikir (Anderson & 4 \\
& & \& Krathwohl, 2017) & \\
\hline 3 & Praktikal & Ketersediaan Alat & 4 \\
& & Ketersediaan Bahan & 4 \\
& & Kesesuaian Langkah Kerja & 4 \\
\hline 4 & Konstruksi Pengetahuan & Judul/Tujuan & 3 \\
& ((Novak \& Gowin, 1984) & Objek Fenomena & 3 \\
\hline
\end{tabular}

\section{HASIL PENELITIAN DAN PEMBAHASAN}

\section{Analisis Aspek Relevansi dengan Kurikulum}

Berdasarkan akumulasi hasil analisis aspek relevansi dengan kurikulum pada kesembilan LKPD (Tabel 2.) yang dilakukan, hasil rata-rata pada parameter relevansi kompetensi maupun konten dengan KD adalah 1. Skor 1 menunjukkan bahwa kompetensi maupun konten yang termuat dalam LKPD belum mencapai standar minimal KD dalam kurikulum yang dipakai. Sedangkan skor 2 menunjukkan bahwa kompetensi maupun konten yang termuat mencapai standar minimal KD dalam kurikulum yang dipakai.

Tabel 2. Hasil Analisis Aspek Relevansi dengan Kurikulum

\begin{tabular}{|c|c|c|c|c|c|c|c|c|c|c|}
\hline \multirow{3}{*}{ Parameter } & \multicolumn{9}{|c|}{ LKPD } & \multirow{3}{*}{ Rata-rata } \\
\hline & \multicolumn{2}{|c|}{2006} & \multirow{2}{*}{$\begin{array}{c}2013 \\
\text { III }\end{array}$} & \multicolumn{6}{|c|}{2013 Revisi 2016} & \\
\hline & I & II & & IV & V & VI & VII & VIII & IX & \\
\hline Kompetensi dengan KD & 1 & 1 & 2 & 1 & 1 & 1 & 1 & 1 & 1 & 1,22 \\
\hline Konten dengan KD. & 1 & 1 & 2 & 1 & 1 & 1 & 2 & 2 & 1 & 1,33 \\
\hline Total & 2 & 2 & 4 & 2 & 2 & 2 & 4 & 3 & 2 & \\
\hline
\end{tabular}

Hasil analisis diatas menunjukkan bahwa baik kompetensi maupun konten yang dikembangkan dalam $9 \mathrm{DKL}$ dari 3 kurikulum yang berbeda belum dapat memenuhi standar minimum KD. Satusatunya DKL yang memenuhi standar minimal KD pada kompetensi dan kontennya hanyalah 1 buku dari kurikulum 2013 yang terbit pada tahun 2014. Sedangkan yang lainnya cenderung tidak memenuhi standar pada kedua parameter. Selanjutnya, hanya ada 2 DKL yang memenuhi standar konten, namun tidak memenuhi standar kompetensinya.

Hal ini tentu disayangkan, karena kegiatan dilakukan membutuhkan waktu yang lebih banyak dibandingkan melalui metode belajar biasa. DKL yang digunakan fokus pada menunjukkan dan membuktikan adanya bintik buta pada mata, padahal tanpa melalui kegiatan ini siswa juga dapat memahaminya melalui teori. Padahal, standar minimal kompetensi yang harus dimiliki dan dikuasai siswa pada kurikulum 2013 revisi 2016 tidak hanya menunjukkan dan membuktikan, melainkan sampai ditahap menganalisis hubungan. Namun, dari 9 DKL pada buku terbitan tahun 2009 hingga 2019 yang 
digunakan sebagai sampel, ditemukan bahwa DKL belum cukup untuk mendukung pencapaian siswa berdasarkan tuntutan KD. Hal ini disebabkan karena kegiatan hanya membuktikan adanya bintik mata tanpa mengaitkannya dengan struktur jaringan maupun mekanisme koordinasi seperti yang diminta dalam KD.

\section{Analisis Aspek Kompetensi}

Hasil analisis aspek kompetensi menunjukan bahwa rata-rata skor perolehan tiap LKPD pada aspek ini sebesar 7,33 dari 16 poin (Tabel 3.). Hal ini menunjukkan bahwa masih LKPD ini belum dapat meningkatkan kemampuan kompetensi yang harus dikuasai siswa

Tabel 3. Hasil Analisis Aspek Kompetensi

\begin{tabular}{|c|c|c|c|c|c|c|c|c|c|c|}
\hline \multirow{3}{*}{ Parameter } & \multicolumn{9}{|c|}{ LKPD } & \multirow{3}{*}{ Rata-rata } \\
\hline & \multicolumn{2}{|c|}{2006} & \multirow{2}{*}{$\frac{2013}{\text { III }}$} & \multicolumn{6}{|c|}{2013 Revisi 2016} & \\
\hline & I & II & & IV & V & Vl & VII & VIII & IX & \\
\hline Kemampuan Observasi & 2 & 2 & 2 & 2 & 2 & 2 & 2 & 2 & 2 & 2 \\
\hline Representasi & 1 & 1 & 2 & 2 & 2 & 2 & 4 & 2 & 2 & 2 \\
\hline Interpretasi & 1 & 1 & 2 & 2 & 2 & 1 & 3 & 2 & 2 & 1,77 \\
\hline $\begin{array}{l}\text { Level Kemampuan } \\
\text { berpikir }\end{array}$ & 1 & 2 & 2 & 1 & 1 & 1 & 2 & 2 & 2 & 1,55 \\
\hline Total & 5 & 6 & 8 & 7 & 7 & 6 & 11 & 8 & 8 & 7,33 \\
\hline
\end{tabular}

Secara umum, kegiatan observasi yang dilakukan pada LKPD ini sudah mencapai karakter umum yang diperlukan untuk dapat menjawab pertanyaan fokus dan memenuhi tujuan dari kegiatan ini. Namun, tentu saja hal ini tidak cukup untuk meningkatkan pengetahuan dan kemampuan siswa lebih luas. Dibutuhkan karakter yang lebih spesifik untuk dapat meningkatkan perolehan pengetahuan dan pemahaman siswa. Pada indikator representasi dan interpretasi data, skor 1 menunjukkan bahwa tidak ada kegiatan representasi dan interpretasi data yang dilakukan pada kegiatan. Sedangkan skor 2 menunjukkan adanya kegiatan representasi data dalam bentuk standar (tabel pengamatan) dan interpretasi data menggunakan tabel hasil pengamatan. LKPD VII mendapat skor 4 pada indikator representasi, karena LKPD tersebut merepresentasikan data hasil pengamatan ke dalam bentuk bagan yang akan dipakai dalam proses interpretasi data selanjutnya. LKPD VII mendapat skor 3 pada interpretasi data, karena siswa diminta menggambarkan hubungan dari data hasil pengamatan dalam bentuk grafik.

Proses representasi dan interpresentasi, tentunya akan berpengaruh pada sejauh apa level kemampuan berpikir siswa berkembang. Kedua hal tersebut akan membantu siswa dalam berpikir pada level yang lebih tinggi. Pada beberapa LKPD, tidak ada kegiatan representasi dan interpretasi, namun level kemampuan berpikirnya dituntut hingga mencapai proses analisis. Hal ini tentunya akan menyulitkan siswa dalam menjawab pertanyaan praktikum. Dari 9 LKPD, 4 diantaranya mengembangkan kemampuan berpikir hanya sampai C3, dan 5 sisanya sampai ke C4. Namun, tidak ada satupun yang dapat mencapai $\mathrm{C} 5$ dan $\mathrm{C} 6$, padahal kegiatan praktikum lebih baik apabila dapat mencapai level kemampuan berpikir yang lebih tinggi.

\section{Analisis Aspek Praktikal}

Hasil analisis pada aspek praktikal menunjukkan hasil yang maksimal pada setiap parameter (Tabel 4.). Kegiatan ini menggunakan alat dan bahan yang dapat dengan mudah ditemukan oleh siswa tanpa harus menggunakan alat laboratorium. Sehingga tidak ada standar tertentu yang perlu dipenuhi 
sesuai standar laboratorium. Karena kegiatan ini cukup mudah, langkah kerja yang diberikan juga terstruktur dan jelas sehingga tidak membingungkan siswa. Beberapa kegiatan memberikan gambar perangkat percobaan, namun walaupun tidak ada gambar tersebut, penjelasan didalam langkah kerja juga cukup dan tidak akan merusak ataupun mengganggu kegiatan siswa.

Tabel 4. Hasil Analisis Aspek Praktikal

\begin{tabular}{|c|c|c|c|c|c|c|c|c|c|c|}
\hline \multirow{3}{*}{ Parameter } & \multicolumn{9}{|c|}{ LKPD } & \multirow{3}{*}{ Rata-rata } \\
\hline & \multicolumn{2}{|c|}{2006} & \multirow{2}{*}{\begin{tabular}{|l|}
2013 \\
III
\end{tabular}} & \multicolumn{6}{|c|}{2013 Revisi 2016} & \\
\hline & $\mathrm{I}$ & II & & IV & $\mathbf{V}$ & $\mathrm{VI}$ & VII & VIII & $\mathrm{IX}$ & \\
\hline Ketersediaan alat & 4 & 4 & 4 & 4 & 4 & 4 & 4 & 4 & 4 & 4 \\
\hline Ketersediaan bahan & 4 & 4 & 4 & 4 & 4 & 4 & 4 & 4 & 4 & 4 \\
\hline Kesesuaian langkah kerja & 4 & 4 & 4 & 4 & 4 & 4 & 4 & 4 & 4 & 4 \\
\hline Total & 12 & 12 & 12 & 12 & 12 & 12 & 12 & 12 & 12 & \\
\hline
\end{tabular}

\section{Analisis Aspek Konstruksi Pengetahuan}

Berdasarkan hasil akumulasi data aspek rekonstruksi pengetahuan, didapatkan 7,66 poin dari 18 poin. Apabila kita telisik satu persatu, kegiatan ini hanya mencapai pada rata-rata skor 1 pada tiap parameter yang diuji.

Tabel 5. Hasil Analisis Aspek Konstruksi Pengetahuan

\begin{tabular}{|c|c|c|c|c|c|c|c|c|c|c|}
\hline \multirow{3}{*}{ Parameter } & \multicolumn{9}{|c|}{ LKPD } & \multirow{3}{*}{ Rata-rata } \\
\hline & \multicolumn{2}{|c|}{2006} & \multirow{2}{*}{$\begin{array}{c}2013 \\
\text { III }\end{array}$} & \multicolumn{5}{|c|}{2013 Revisi 2016} & \multirow[b]{2}{*}{ IX } & \\
\hline & $\mathrm{I}$ & II & & IV & $\mathbf{V}$ & VI & VII & VIIII & & \\
\hline Judul/Tujuan & 1 & 1 & 2 & 0 & 1 & 1 & 3 & 3 & 2 & 1,55 \\
\hline Objek Fenomena & 1 & 1 & 2 & 1 & 1 & 1 & 2 & 2 & 2 & 1,44 \\
\hline Teori, prinsip dan konsep & 1 & 1 & 2 & 1 & 1 & 1 & 2 & 2 & 1 & 1,33 \\
\hline $\begin{array}{l}\text { Perekaman dan } \\
\text { transformasi data }\end{array}$ & 0 & 0 & 4 & 1 & 1 & 1 & 4 & 2 & 1 & 1,55 \\
\hline Perolehan Pengetahuan & 1 & 1 & 3 & 1 & 1 & 1 & 3 & 3 & 2 & 1,77 \\
\hline Total & 4 & 4 & 13 & 4 & 5 & 5 & 14 & 12 & 8 & 7,66 \\
\hline
\end{tabular}

Judul, tujuan dan pertanyaan fokus yang ada pada tiap LKPD cenderung dapat diidentifikasi dan konsisten. Pemberian skor 1 karena judul/tujuan/pertanyaan fokus tidak mengandung bagian konseptual yang diperlukan siswa. Skor 2 pada LKPD III dan IX menunjukkan bahwa judul/tujuannya mengandung bagian konseptual yang akan digunakan, namun tidak mendukung observasi pada peristiwa utamanya. Sedangkan skor 3 pada LKPD VII dan VIII sebagai skor tertinggi pada indikator ini karena judul/tujuan meliputi bagian konseptual yang akan diamati dan mendukung peristiwa utama. Pembuatan judul dan tujuan serta pertanyaan fokus perlu dilakukan untuk membantu siswa dalam memahami apa yang hendak dilakukan serta kemampuan apa yang akan dimilikinya (Novak \& Gowin, 1984).

Pada indikator objek fenomena yang diamati, seluruh LKPD memiliki peristiwa yang dapat diamati yang konsisten dengan pertanyaan fokus. Tidak banyak konsep yang dapat diidentifikasi melalui kegiatan ini, bahkan cenderung tidak perlu dilakukan kegiatan praktikum untuk menjawab pertanyaan fokus yang diberikan. Hanya pada LKPD III, VII dan VIII saja yang dapat mengidentifikasi konsep lain karena konsep tersebut hanya akan ditemukan dengan melakukan kegiatan.

Pada LKPD dari buku dengan KTSP 2006, tidak dilakukan proses perekaman data karena kegiatan hanya memfokuskan pada pembuktian bahwa bintik buta ada. Padahal, tanpa melalui kegiatan ini pun siswa dapat mengetahui hal tersebut. Proses perekaman data dengan skor tertinggi didapatkan 
pada LKPD III dan VII, dimana pada kegiatan tersebut hasil perekaman dan transformasi data konsisten dan dipakai untuk menjawab pertanyaan fokus dengan lebih spesifik. Sedangkan pada LKPD VIII dengan skor 2, kegiatan perekaman data dapat diidentifikasi dan konsisten dengan pertanyaan fokus. LKPD lainnya melakukan kegiatan perekaman data, namun tidak konsisten dengan pertanyaan fokusnya.

Seluruh parameter dari judul hingga perekaman data berpengaruh secara signifikan pada perolehan pengetahuan yang didapatkan oleh siswa. Melalui kegiatan ini, perolehan pengetahuan tentu akan didapatkan oleh siswa. Namun, tingkat perolehannya ditentukan oleh bagaimana kegiatan tersebut dilakukan secara keseluruhan. Pada LKPD dengan skor rendah dari parameter judul hingga perekaman, tingkat perolehan pengetahuannya juga rendah karena tidak sesuai dengan bagian kiri pada diagram Vee. Hal ini ditandai dengan tidak konsistennya judul, tujuan, pertanyaan fokus, kegiatan serta fenomena yang diamati pada LKPD. Ketika hal-hal tersebut konsisten dan berkaitan, maka perolehan pengetahuannya juga akan meningkat dan mengandung sisi konseptual yang diperlukan siswa.

\section{Hasil Uji Coba LKPD}

Uji coba dilakukan pada salah satu dari 9 sampel LKPD yang dipakai pada analisis sebelumnya. Berdasarkan kegiatan praktikum tersebut, dilakukan analisis konten yang ada pada LKS dengan membandingkan konten dan relevansinya dengan kurikulum serta kegiatan yang dilakukan dalam praktikum. Dari hasil uji coba, LKPD ini belum dapat memenuhi kompetensi dasar yang dibutuhkan siswa. Hal ini disebabkan karena pada kegiatan yang di uji coba, siswa hanya diminta untuk merasakan adanya fenomena dimana suatu benda tidka terlihat pada titik tertentu. Padahal berdasarkan kurikulum, KD yang harus dicapai siswa adalah menjelaskan keterkaitan antara struktur, fungsi dan prosesnya. prosedur kerja yang terlalu sederhana dan tidak ada variasi kegiatan tidak menjelaskan konsep apapun bagi siswa. Tidak adanya kegiatan pengisian data dan pertanyaan praktikum menyebabkan kegiatan ini tidak memiliki makna yang cukup untuk siswa menguasasi konsep.

Maka, berdasarkan hasil analisis kegiatan siswa, kegiatan ini membutuhkan banyak revisi dalam variasi prosedur kerja, pertanyaan dan pencatatan data hasil kegiatan. Sebaiknya ditambahkan juga beberapa perlakuan untuk membuat kegiatan ini mencapai kompetensi yang lebih luas dan bukan hanya sekedar bintik buta. Kegiatan praktikum pada sistem indera sangat jarang dilakukan di sekolah karena dianggap tidak begitu penting. Padahal, kegiatan pada sistem indera dibutuhkan untuk menjelaskan hubungannya dengan sistem koordinasi lainnya

\section{Rekonstruksi LKPD}

Berdasarkan hasil analisis menggunakan instrumen yang telah dibuat, ditemukan bahwa LKPD tersebut belum cukup mampu memenuhi tuntutan kurikulum dan membantu siswa dalam mengonstruksi pengetahuan. Ada banyak sekali kekurangan dalam seluruh LKPD. Maka dari itu, perlu dilakukan rekonstruksi dan pengembangan terhadap LKPD sehingga dapat menghasilkan LKPD dengan skor yang tinggi berdasarkan parameter yang sudah dibuat dan mencapai tujuan kegiatan yang tepat. 


\section{Tujuan :}

\section{Indera Penglihatan - Bintik Buta pada Mata}

- Siswa mampu menentukan letak bintik buta

- Siswa mampu menjelaskan fenomena berkaitan dengan bintik buta

- Siswa mampu mengaitkan hubungan antara indera penglihatan dan sistem koordinasi

\section{Alat dan Bahan}

Alat :

- Karton putih

- Karton berwarna

- Spidol hitam

- Penggaris

- Gunting

\section{Langkah Kerja :}

\section{Kegiatan 1.}

1. Siapkan alat dan bahan yang dibutuhkan

2. Potonglah karton berukuran $10 \times 25 \mathrm{~cm}$

3. Buatlah sebuah kotak berukuran $1 \times 1 \mathrm{~cm}$ dan lingkaran berdiameter $1 \mathrm{~cm}$, keduanya berjarak 10 $\mathrm{cm}$. Perhatikan gambar 1.

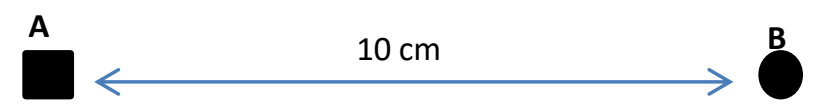

Gambar 1. Desain Kegiatan 1

4. Pegang kertas sejauh rentangan tangan, tutup mata kanan dan fokuskan pandangan pada kotak A. Pada saat ini, pastikan bahwa lingkaran B masih terlihat.

5. Dekatkan kertas ke arah mata secara perlahan, hingga lingkaran $B$ menghilang.

6. Perhatikan bahwa lingkaran B mungkin menghilang dan muncul kembali, minta temanmu mengukur jarak antara kertas dan mata ketika hal tersebut terjadi.

7. Ulangi kegiatan tersebut dengan mengubah fokus pada lingkaran $B$.

8. Lakukan lagi kegiatan 4-7 dengan bergantian menutup mata sebelah kiri.

9. Buatlah kembali kotak $A$ dan lingkaran $B$ dengan membuat jarak sejauh $20 \mathrm{~cm}$. Lalu ulangi lagi kegiatan ini.

10. Tuliskan hasil pengamatan mu. 
Tabel Pengamatan 1. Hasil Kegiatan 1

\begin{tabular}{ccccc}
\hline & \multicolumn{2}{c}{ Mata Kanan } & \multicolumn{2}{c}{ Mata Kiri } \\
\cline { 2 - 4 } & Hilang & Tampak & Hilang & Tampak \\
\hline Lingkaran & & & \\
Kotak & & & \\
\hline
\end{tabular}

\section{Kegiatan 2.}

1. Potonglah karton berukuran $10 \times 25 \mathrm{~cm}$

2. Tanpa membuat garis, buatlah empat titik dalam garis lurus yang berjarak $5 \mathrm{~cm}$ tiap titiknya, tandai setiap titik dengan $\mathrm{A}$ sampai $\mathrm{D}$, atau perhatikan gambar 2 .

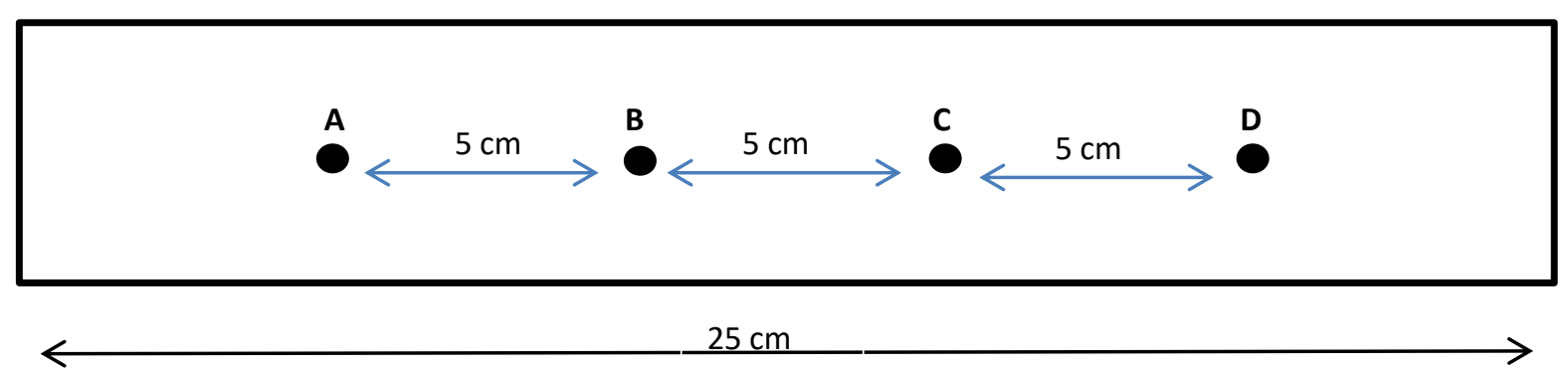

Gambar 2. Desain Kegiatan 2

3. Pegang kertas sejauh rentangan tangan, tutup mata kanan dan fokuskan pandangan pada titik A.

4. Dekatkan kertas ke arah mata secara perlahan, perhatikan apakah ada titik yang tidak terlihat lagi. Minta temanmu untuk membantu mengukur jarak antara mata dengan kertas ketika ada titik yang tidak terlihat.

5. Ulangi hal tersebut dengan mengganti fokus pada titik $D$.

6. Lakukan lagi langkah 4-6 dengan bergantian menutup mata sebelah kiri.

7. Tuliskan hasil pengamatanmu.

Tabel Pengamatan 2. Hasil Kegiatan 2

\begin{tabular}{cccc}
\hline \multicolumn{2}{c}{ Mata Kanan } & \multicolumn{2}{c}{ Mata Kiri } \\
\hline Titik yang Hilang & Jarak & Titik yang Hilang & Jarak \\
\hline & & \\
\hline
\end{tabular}

\section{Kegiatan 3.}

1. Potonglah karton berukuran $25 \times 10 \mathrm{~cm}$.

2. Buatlah 1 lingkaran dengan diameter $1 \mathrm{~cm}$ diantara dua persegi panjang berukuran $5 \times 0,5 \mathrm{~cm}$, dengan jarak $0,5 \mathrm{~cm}$ antara kedua persegi panjang dengan lingkaran. Lalu, dari persegi panjang sebelah kanan, buatlah persegi panjang berukuran $1 \times 0,5 \mathrm{~cm}$ dengan jarak keduanya $5 \mathrm{~cm}$. Atau perhatikan gambar berikut : 


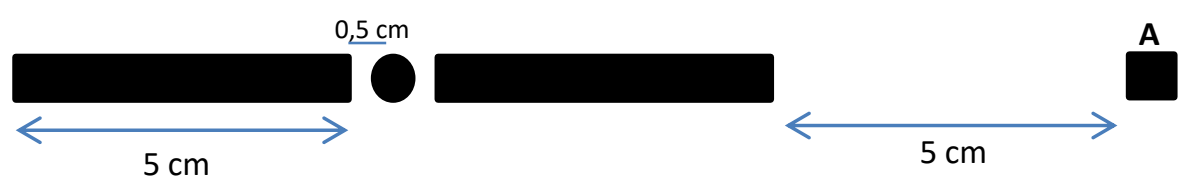

Gambar 3. Desain Kegiatan 3

3. Pegang kertas sejauh rentangan tangan, tutup mata sebelah kanan dan pusatkan pandangan pada kotak $A$.

4. Dekatkan kertas ke arah mata secara perlahan. Perhatikan bagaimana keadaan lingkaran dan persegi panjang, dengan mata tetap fokus pada kotak $A$.

5. Ulangi kegiatan 3-4 dengan bergantian menutup mata sebelah kiri, pandangan tetap terpusat pada kotak $A$.

6. Menggunakan kertas berwarna, ulangi kegiatan ini untuk mendapat variasi berbeda.

7. Tuliskan hasil pengamatanmu.

\section{Pertanyaan Praktikum :}

1. Apa yang terjadi pada objek yang tidak menjadi fokus penglihatanmu, ketika kertas didekatkan ke arah mata? Mengapa demikian?

2. Bagaimana pengaruh jarak antara kertas dengan mata mempengaruhi keadaan tersebut? Bandingkan dengan hasil pengamatan pada kegiatan 1 dan 2!

3. Dengan menggunakan hasil pengamatan 1 dan 2 , gambarlah suatu bagan untuk menunjukkan letak titik buta yang kamu alami!

4. Apa yang terjadi pada lingkaran dan persegi panjang di kegiatan 3? Adakah perbedaan yang muncul ketika menggunakan kertas putih dan kertas berwarna? Mengapa demikian?

5. Bagaimana kamu dapat menjelaskan hubungan antara kegiatan ini dengan mekanisme pada sistem koordinasi?

\section{SIMPULAN}

Berdasarkan hasil analisis yang telah dilakukan ditemukan bahwa kegiatan praktikum mengenai sistem indera penglihatan sangat terbatas dalam menentukan titik buta. Kegiatan tersebut belum mampu mencapai standar minimal kompetensi karena tidak menghubungkan antara mata dengan mekanisme koordinasi pada manusia. Dari berbagai buku dari 3 kurikulum yang berbeda, ditemukan bahwa terdapat kesamaan pada kegiatannya. Hal ini menunjukkan bahwa tidak ada perubahan berarti pada kegiatan praktikum sistem indera penglihatan, bahkan setelah berkali-kali terjadi perubahan kurikulum. Maka, pengembangan LKPD dengan menambahkan kriteria tambahan dan jenis kegiatan lainnya mesti dilakukan agar dapat membantu siswa dalam memahami kaitannya.

\section{RUJUKAN}

Abrahams, I., \& Millar, R. (2008). Does Practical Work Really Work? A study of the effectiveness of practical work as a teaching and learning method in school science. International Journal of Science Education. 1-25. DOI: 10.1080/09500690701749305 
Anderson, L. W., Krathwohl, D. R. (2017). Kerangka Landasan Untuk Pembelajaran, Pengajaran, dan Asesmen (Revisi Taksonomi Pendidikan Bloom). Yogyakarta: Pustaka Pelajar

Attard, A., et al. (2010). Student Centered Learning an Insight Into Theory and Practice. Bucharest:

Partos Timisora

Arikunto, S. (2003). Manajemen Penelitian. Jakarta: Rineka Cipta

Bertin, J. (1983). Semiology of Graphic. Wincounsin: University of Wincounsin Press

Creswell, J. W. (2016). Research Design (4th ed.). Yogyakarta: Pustaka Pelajar

Furqan, H., Yuszrizal, \& Saminan. (2016). Pengembangan Modul Praktikum Berbasis Inkuiri untuk Meningkatkan Keterampilan Proses Sains dan Hasil Belajar Siswa Kelas X di SMA Negeri 1 Bukit Bener Meriah. Jurnal Pendidikan Sains Indonesia. 4(2). 124-129

Hidayah, A.S. (2012). Manajemen Sekolah Berbasis Karakter. Jurnal Inovasi dan Kewirausahaan. 1(1). $8-22$

Hidayati, N. (2015). Pengembangan Lembar Kegiatan Siswa Materi Sistem Saraf, Indera dan Hormon. Saintifika. 17(2). 1-9

Hindriana, A.F. (2016). The Development of Biology Practicum Learing based on Vee Diagram for Reducing Student Cognitive Load. Journal of Education, Teaching and Learning. 1(2). 61-65

Kemendikbud. (2018). Peraturan Mentri Pendidikan dan Kebudayaan Republik Indonesia Nomor 37 Tahun 2018. Jakarta.

Lahra, A.S., Hasan, M., Mursal. (2017). Pengembangan Modul Praktikum Berbasis Pendekatan Open Ended untuk Meningkatkan Kreativitas Siswa. Jurnal Pendidikan Sains Indonesia. 5(1). 36-43

Lestari, R., Supriatno, B., \& Anggraeni, S. (2020). Analisis Konseptual, Praktikal, Konstruksi Pengetahuan dan Rekonstruksi Lembar Kerja Praktikum Enzim Katalase. Biodik : Jurnal IImiah Pendidikan Biologi. 6(4). 476-491

Novak, J. D., \& Gowin, D. B. (1984). Learning How to Learn. Journal of Chemical Information and Modeling (Vol. 53). New York: Cambridge University Press

Okam, C.C \& Zakari, I.I. (2017). Impact of Laboratory-Based Teaching Startegy on Students' Attitudes and Mastery of Chemistry in Katsina Metropolis. International Journal of Innovative Research and Development. 6(1). 112-121

Prabowo, A., Heriyanto. (2013). Analisis Pemanfaatan Buku Elektronik (E-book) oleh Pemustaka di Perpustakaan SMA Negeri 1 Semarang. Jurnal IImu Kepustakaan. 2(2). 1-9

Ramadhayanti, Anggraeni, S., \& Supriatno, B. (2020). Analisis dan Rekonstruksi Lembar Kerja Peserta Didik Indra Pengecap Berbasis Diagram Vee. Biodik:Jurnal IImiah Pendidikan Biologi. 6(2). 200213. https://doi.org/10.22437/bio.v6i2.9441

Ritonga, N. (2016). Analisis Kesulitan Belajar pada Materi Pokok Sistem Pernapasan Manusia di SMP Abdi Negara Asam Jawa. Wahana Inovasi. 5(2). 409-415

Shana, Z.J., \& Abulibdeh, E.S. (2020). Science Practical Work and Its Impact on Students' Science Achievement. Journal of Technology and Science Education. 10(2). 199-215. https://doi.org/10.3926/jotse.888

Supriatno, B. (2018). Praktikum untuk Membangun Kompetensi. Proceeding Biology Education Conference. 15 (1). 1-18. Retrieved from https://jurnal.uns.ac.id/prosbi/article/view/27558/19050

Wahidah, N.S., Supriatno, B., Kusumastuti, M.N. Analisis Struktur dan Kemunculan Tingkat Kognitif pada Desain Kegiatan Laboratorium Materi Fotosintesis. Indonesian Journal of Biology education. 1(2). 70-76 